\title{
Originals
}

\section{The immune response to influenza vaccination in diabetic patients}

\author{
P. Pozzilli ${ }^{1,3}$, E. A.M. Gale ${ }^{3}$, N. Visalli ${ }^{1}$, M. Baroni ${ }^{1}$, P.Crovari ${ }^{2}$, V. Frighi ${ }^{1}{ }^{3}$, M. G. Cavallo ${ }^{1}$ and D. Andreani ${ }^{1}$ \\ ${ }^{1}$ Cattedra Endocrinologia (I), 2nd Clinica Medica, University of Rome "La Sapienza", Rome, and \\ ${ }^{2}$ Istituto d'Igiene, University of Genoa, Genoa, Italy; \\ ${ }^{3}$ Department of Diabetes and Immunogenetics, St. Bartholomew's Hospital, London, UK
}

Summary. The immune response of diabetic patients to influenza vaccination was examined in 31 patients, 10 with Type 1 (insulin-dependent) diabetes and 21 with Type 2 (non-insulindependent diabetes), and in 19 normal subjects. Each received a single intramuscular injection of the 3 virus strains (A/ Chile,A/Philippines, B/USSR) anti-influenza vaccine recommended by WHO. The antibody titre and the cell-mediated immune response to the 3 virus strains, as evaluated by the generation of activated lymphocytes and enumeration of $\mathrm{B}$ lymphocytes, were studied before and $18 \mathrm{~h}, 72 \mathrm{~h}$ and $1,2,3$ and 6 weeks after vaccination. Overall, the humoral and cellmediated immune responses were normal in both groups of patients. However, patients with Type 1 diabetes showed a statistically significant increase $(p<0.01)$ of antibody titre of the
$\mathrm{A} /$ Chile and an increased percentage of B lymphocytes one week after vaccination compared to age-matched control subjects. Four out of 21 patients with Type 2 diabetes had no antibody response to all 3 virus strains. A significant reduction $(p<0.01)$ of the percentage of activated cells possessing receptors for interleukin- 2 was observed $72 \mathrm{~h}$ after vaccination in patients with Type 2 diabetes compared to age-matched control subjects. None of the patients who received the vaccine developed influenza in the course of the following year. These results suggest that valid protection against the influenza virus can be obtained in patients with Type 1 and Type 2 diabetes.

Key words: Type 1 diabetes, Type 2 diabetes, influenza vaccination, immune response in diabetes.
Influenza is the only remaining major epidemic viral disease. Immunization is often performed, although the protective effect reported in different studies varies considerably [1-3]. Current recommendations advise annual vaccination of certain groups in the population considered to be at high risk [4].

Patients with Type 1 (insulin-dependent) and Type 2 (non-insulin-dependent) diabetes of long duration may be predisposed to viral as well as bacterial infections [5-7]. Poor metabolic control has been suggested as the cause of several abnormalities in the immune response including impaired phagocytosis [8], increased circulating immune complexes [9], reduced lymphocyte transformation [10] and decreased percentage of $T$ cells [11]. In view of these findings, some patients may be considered as having secondary immunodeficiency [12].

Infectious diseases, and in particular influenza, are a common cause of clinical instability in patients with diabetes and may precipitate diabetic ketoacidosis. It is not known whether patients with long standing diabetes develop influenza more frequently than normal subjects as a consequence of an altered immune response.
Therefore, in the present study we have investigated the humoral and cell-mediated immune response of diabetic patients following vaccination with influenza virus.

\section{Subjects and methods}

\section{Subjects}

Following approval by the Ethical Committee, informed consent was obtained from the diabetic patients and control subjects. The groups were made up as follows:

10 patients with Type 1 diabetes ( 3 females and 7 males, mean age $36 \pm 14$, duration of disease of $15 \pm 12$ years); 21 patients Type 2 with diabetes ( 9 females and 12 males, mean age $54 \pm 13$, duration of disease of $11 \pm 7$ years); 9 normal subjects ( 14 females and 5 males, mean age $32 \pm 8$ ) as the control group for Type 1 diabetic patients; 10 normal subjects ( 5 females and 5 males, mean age $52 \pm 11$ ) as the control group for Type 2 diabetic patients. Investigations in the patients included evaluation of metabolic control [fasting blood glucose and $\mathrm{HbA}_{1}$ using ion exchange chromatography (normal range $4.0-7.0 \%$, Biorad, Milan, Italy)] and routine blood tests (white cell and erythrocyte count, serum creatinin, protein electrophoresis, blood urea nitrogen, serum lipoproteins and liver enzymes). 
Table 1. Clinical data of Type 1 and Type 2 diabetic patients

\begin{tabular}{|c|c|c|c|c|c|c|c|}
\hline$\overline{\operatorname{Sex}}$ & Age & $\begin{array}{l}\text { Duration of disease } \\
\text { (years) }\end{array}$ & $\begin{array}{l}\text { Blood glucose } \\
(\mathrm{mmol} / 1)^{\mathrm{a}}\end{array}$ & $\begin{array}{l}\mathrm{HbA}_{1} \\
(\%)\end{array}$ & Complications & Therapy & $\begin{array}{l}\text { Associated } \\
\text { diseases }\end{array}$ \\
\hline \multicolumn{8}{|c|}{ Type 1 diabetic patients } \\
\hline $\mathrm{M}$ & 25 & 6 & $5.0 \pm 1.5$ & 5.1 & Absent & Insulin & Absent \\
\hline M & 21 & 14 & $9.5 \pm 4.0$ & 9.6 & Absent & Insulin & Absent \\
\hline $\mathrm{M}$ & 22 & 6 & $12.0 \pm 5.0$ & 8.6 & Absent & Insulin & Absent \\
\hline M & 28 & 8 & $4.6 \pm 3.1$ & 3.8 & Absent & Insulin & Absent \\
\hline $\mathrm{F}$ & 36 & 4 & $8.8 \pm 2.0$ & 6.5 & Absent & Insulin & Absent \\
\hline $\mathrm{M}$ & 33 & 8 & $7.9 \pm 4.2$ & 7.0 & Absent & Insulin & Dental abscess \\
\hline $\mathrm{F}$ & 35 & 11 & $7.6 \pm 4.3$ & 7.2 & Absent & Insulin & Dental abscess \\
\hline$F$ & 44 & 42 & $16.6 \pm 3.1$ & 8.2 & Retinopathy & Insulin & Dental abscess \\
\hline $\mathrm{M}$ & 58 & 24 & $9.5 \pm 3.5$ & 8.2 & Retinopathy & Insulin & Dental abscess \\
\hline M & 62 & 27 & $10.5 \pm 5.1$ & 8.0 & Retinopathy & Insulin & Dental abscess \\
\hline \multicolumn{8}{|c|}{ Type 2 diabetic patients } \\
\hline $\mathrm{M}$ & 27 & 8 & $6.5 \pm 1.5$ & 6.1 & Absent & $\mathrm{OHA}{ }^{c}$ & Absent \\
\hline $\mathrm{F}$ & 40 & 3 & $5.9 \pm 1.1$ & 5.5 & Absent & Diet only & Absent \\
\hline $\mathrm{F}$ & 41 & 15 & $9.8 \pm 1.9$ & 9.5 & Absent & $\mathrm{OHA}^{\mathrm{c}}$ & Absent \\
\hline $\mathrm{F}$ & 49 & 8 & $6.0 \pm 1.1$ & 6.3 & Absent & $\mathrm{OHA}^{\mathrm{c}}$ & Absent \\
\hline $\mathrm{M}$ & 46 & 14 & $10.3 \pm 1.8$ & 5.6 & Absent & $\mathrm{OHA}^{\mathrm{c}}$ & Absent \\
\hline $\mathrm{F}$ & 41 & 2 & $6.9 \pm 2.1$ & 5.2 & Absent & Diet only & Absent \\
\hline $\mathrm{M}$ & 45 & 1 & $6.6 \pm 3.2$ & 5.3 & Absent & Diet only & Absent \\
\hline $\mathrm{F}$ & 62 & 5 & $8.3 \pm 0.8$ & 6.6 & Absent & $\mathrm{OHA}^{c}$ & Absent \\
\hline $\mathrm{F}$ & 74 & 3 & $6.5 \pm 1.1$ & 6.5 & Absent & Diet only & Absent \\
\hline $\mathrm{F}$ & 33 & 6 & $6.8 \pm 0.8$ & 5,4 & Absent & $\mathrm{OHA}^{\circ}$ & Absent \\
\hline $\mathrm{M}$ & 53 & 16 & $6.0 \pm 1.8$ & 6.5 & Retinopathy & OHA & Absent \\
\hline M & 58 & 29 & $12.0 \pm 1.5$ & 7.0 & Prol. retin. & Insulin & Absent \\
\hline $\mathrm{M}$ & $58^{\mathrm{b}}$ & 16 & $6.9 \pm 1.8$ & 5.8 & Retinopathy & $\mathrm{OHA}^{\mathrm{c}}$ & Absent \\
\hline M & 59 & 21 & $5.6 \pm 2.1$ & 5.3 & Retinopathy & $\mathrm{OHA}^{\mathrm{C}}$ & Absent \\
\hline M & 61 & 16 & $9.8 \pm 2.2$ & 8.6 & PVD $^{d}$ & $\mathrm{OHA}^{\mathrm{C}}$ & Absent \\
\hline $\mathrm{M}$ & 62 & 15 & $7.4 \pm 2.2$ & 6.4 & PVD $^{d}$ & $\mathrm{OHA}^{\mathrm{C}}$ & Absent \\
\hline M & 63 & 15 & $6.0 \pm 1.2$ & 4.4 & Retinopathy & $\mathrm{OHA}^{\mathrm{c}}$ & Bronchitis \\
\hline $\mathrm{M}$ & $68^{\mathrm{b}}$ & 10 & $10.2 \pm 1.2$ & 6.8 & Retinopathy & $\mathrm{OHA}^{\mathrm{c}}$ & Absent \\
\hline $\mathrm{F}$ & 52 & 2 & $7.6 \pm 1.2$ & 7.0 & Retinopathy & $\mathrm{OHA}^{\mathrm{C}}$ & Absent \\
\hline $\mathrm{F}$ & $79^{b}$ & 11 & $6.7 \pm 1.8$ & 5.3 & Retinopathy & $\mathrm{OHA}^{\mathrm{c}}$ & Absent \\
\hline M & $69^{b}$ & 17 & $4.9 \pm 1.4$ & 5.3 & Nephropathy & $\mathrm{OHA}^{\mathrm{c}}$ & Absent \\
\hline
\end{tabular}

${ }^{a}$ Mean of seven determinations over the course of the study; ${ }^{b}$ anergic patients to all virus strains; ${ }^{c}$ oral hypoglycaemic agents; ${ }^{d}$ peripheral vascular disease

The clinical characteristics of patients studied are shown in Table 1 . The control group was composed of subjects with no family history of diabetes or other autoimmune diseases; they were all in good health at the time of vaccination.

\section{Methods}

Anti-influenza vaccine was prepared by the Institute Merieux (Lyon, France) and given as a single intramuscular injection $(0.5 \mathrm{ml})$. A trivalent, inactivated prearation was used containing antigens representative of the following strains of influenza viruses recommended for the 1984/85 prophylaxis: A/Chile (HIN1); A/Philippines (H3N2); B/ USSR $/ 100 / 83$. The vaccine contained 15 ug of each haemagglutinin antigen. Blood samples for immunological studies were collected before vaccination and $18 \mathrm{~h}, 72 \mathrm{~h}$ and 1,2, 3 and 6 weeks. Antibody titres to the 3 virus strains contained in the vaccine were measured using the single radial haemolysis (SRH) technique (13). The haemolysis was read using a diffusion zone reader (Dynatech) after incubation of plates at $37^{\circ} \mathrm{C}$ for $3 \mathrm{~h}$. The results are expressed as mean area in $\mathrm{mm} \pm \mathrm{SD}$.

\section{Cell-mediated immunity}

The generation of activated lymphocytes was evaluated using two monoclonal antibodies, one of which detects an early activation antigen on lymphocyte surface (4F2) [14] and the other which phenotypes cells with receptors for interleukin-2 (anti-Tac) [15]. B lymphocytes were measured using the $\mathrm{L} 243$ monoclonal antibody [16]. Lymphocytes positive for each monoclonal antibody used were evaluated by the indirect immunofluorescence technique. Briefly, $5 \times 10^{5}$ cells were incubated with $50 \mu \mathrm{l}$ of the relevant monoclonal antibody for $30 \mathrm{~min}$ at $4^{\circ} \mathrm{C}$. Cells were then washed, incubated with $\operatorname{IgG}$ goat antimouse fluorescinated antiserum for $30 \mathrm{~min}$ at $4{ }^{\circ} \mathrm{C}$, washed three times and finally placed on a multiwell plate (Hamax, Medicell International, London, UK) for the count of positive cells using an inverted microscope as previously described [17].

\section{Statistical analysis}

Statistical analysis included Mann-Whitney $U$ test and analysis of variance (repeated measurement design); significance was established as $p<0.05$.

\section{Results}

\section{Humoral immune response}

In normal subjects an antibody response to the virus was obtained which followed the expected pattern [1-3]. The antibody titre to the different influenza virus strains reached its maximum 1-2 weeks after administration of vaccine in both control subjects and diabetic 

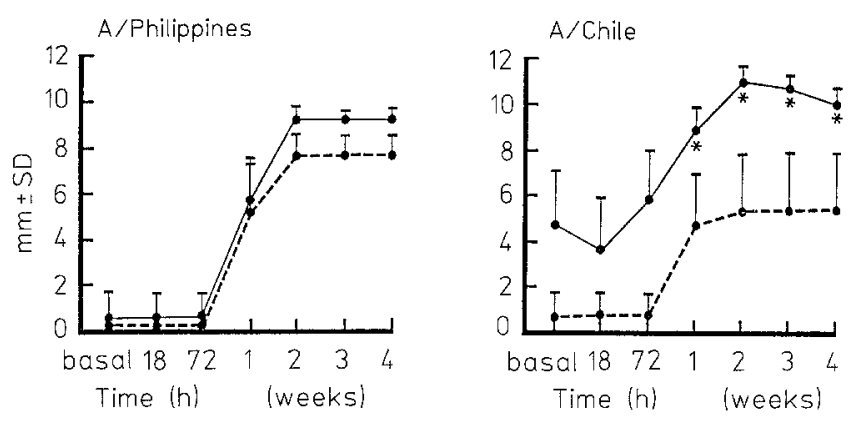

B/USSR

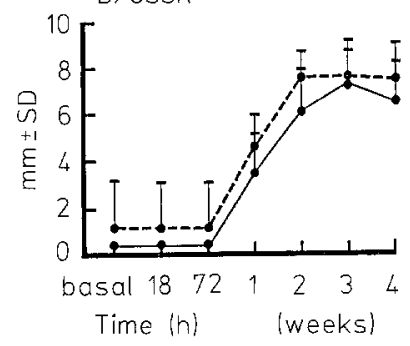

Fig. 1. The humoral immune response to three strains of influenza virus as calculated by single radial haemolysis (SRH) and expressed as mean area in $\mathrm{mm}+\mathrm{SD}$ following the administration of anti-influenza vaccine in Type 1 diabetic patients $(-1)$ ) and age-matched control subjects (-- ) ${ }^{*} p<0.01$
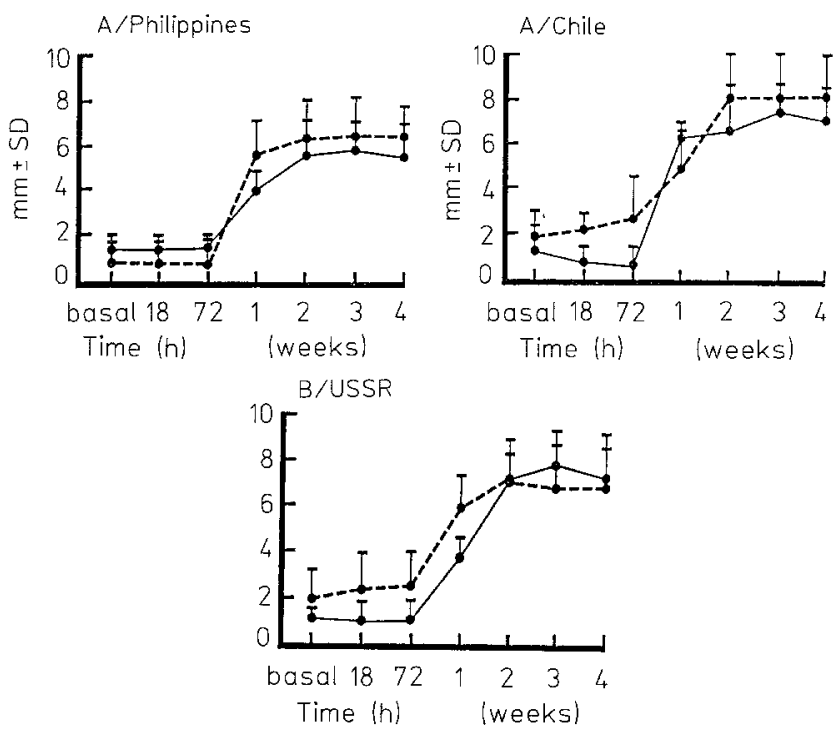

Fig. 2. The humoral immune response to three strains of influenza virus as calculated by SRH and expressed as mean area in $\mathrm{mm}+\mathrm{SD}$ following the administration of anti-influenza vaccine in patients with Type 2 diabetes $(-$ ) and age-matched control subjects

patients and remained stable afterwards (up to week 6 after vaccination).

All patients with Type 1 diabetes showed a satisfactors response to $\mathrm{A} /$ Chile and $\mathrm{A} /$ Philippines virus strains. There were 6 subjects ( 3 patients and 3 control subjects) who did not respond to the B/USSR strain. The overall humoral immune response in patients with Type 1 diabetes is shown in Figure 1. A statistically significant increase of the antibody titre to the $\mathrm{A} /$ Chile
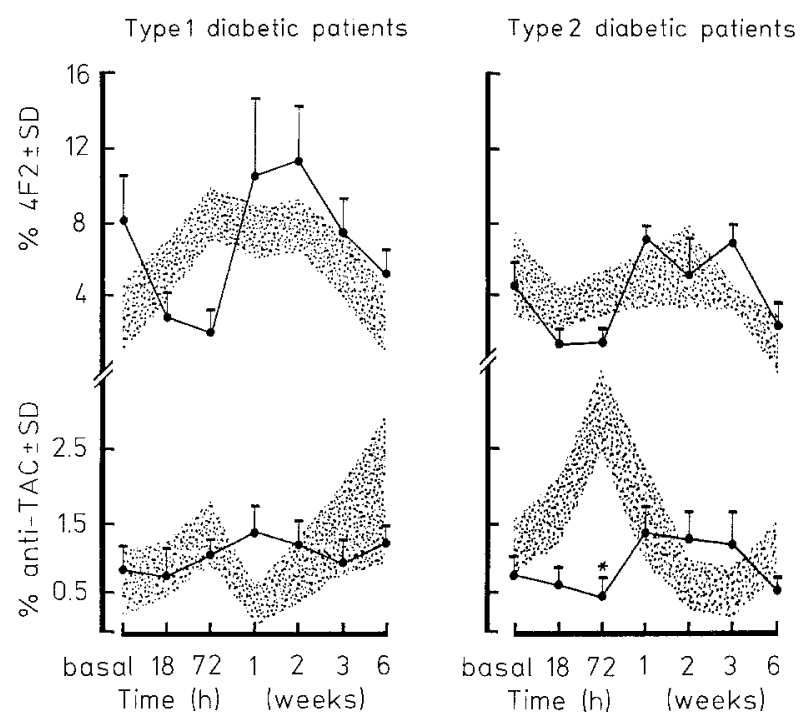

Fig. 3. The generation of activated lymphocytes (as evaluated by the percentage $\pm \mathrm{SD}$ of $4 \mathrm{~F} 2$ and anti-TAC positive cells) following the administration of anti-influenza vaccine in Type $1(n=10)$ and Type 2 $(n=21)$ diabetic patients. The shaded areas represent the normal range in age-matched control subjects. ${ }^{*} p<0.01$
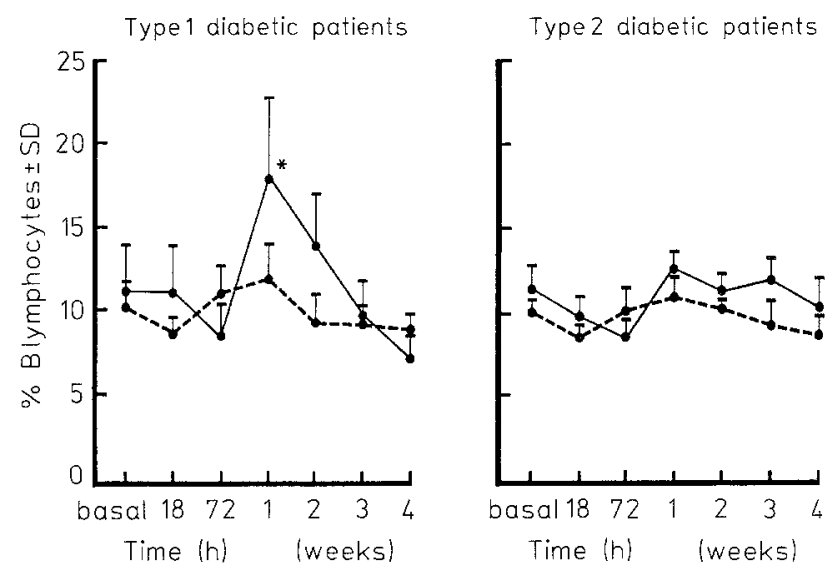

Fig.4. The percentage + SD of B lymphocytes following the administration of anti-influenza vaccine in Type $1(n=10)$ and Type $2(n=21)$ diabetic patients $(\longrightarrow)$ and in age-matched control subjects $(\bullet-\cdots) \cdot{ }^{*} p<0.02$

strain $(p<0.01)$ and no differences in the antibody titres to A/Philippines and B/USSR were observed compared to age-matched control subjects.

In patients with Type 2 diabetes, $4(19 \%)$ were nonresponders to all 3 virus strains as opposed to 1 subject in the age-matched control group. When the antibody responses to single $\mathrm{B} / \mathrm{USSR}, \mathrm{A} /$ Philippines and $\mathrm{A} /$ Chile strains were considered, no significant differences were observed with age-matched control subjects 
(Fig. 2). A normal antibody titre to B/USSR was reached in $67 \%$ of patients and control subjects, and to $\mathrm{A} /$ Philippines and $\mathrm{A} /$ Chile in $72 \%$ and $78 \%$ respectively.

\section{Cell-mediated immune response}

Figure 3 shows the results of activated lymphocytes in patients with Type 1 diabetes and Type 2 diabetes. The shaded areas represent the values in age-matched control subjects for each group of patients. Overall, a wide variation of the percentage of activated cells was observed in patients and control subjects following vaccination. The only statistically significant difference was the reduction of anti-TAC positive lymphocytes in patients with Type 2 diabetes compared to normal subjects $72 \mathrm{~h}$ after vaccination, at the time when the generation of activated cells reaches the peak in normal subjects $(p<0.01)$.

No significant changes were observed in the percentage of B lymphocytes except for patients with Type 1 diabetes 1 week after vaccination. Thus, a significant increase of the percentage of L243 positive cells was found compared to normal subjects $(p<0.02)$. Glycosylated haemoglobin values were $7.2 \% \pm 1.7$ in patients with Type 1 diabetes and $6.2 \% \pm 1.2$ in those with Type 2 diabetes (normal range of the method 4-7\%).

\section{Discussion}

Overall, the immune response to influenza vaccination in Type 1 and Type 2 diabetic patients does not differ from that observed in age-matched normal subjects, indicating that influenza vaccination may be beneficial in these patients. It should be mentioned that our patients were reasonably controlled at the time of vaccination, and this could have been relevant for the positive response to the virus. However, in the light of previous work suggesting an impaired immune response in poorly controlled patients [18], we can not exclude the possibility that patients with poor metabolic control might have an attenuated immune response to the virus following vaccination. On the other hand, we would emphasize that patients with Type 1 diabetes showed a prompt and (in the case of $\mathrm{A} / \mathrm{Chile}$ strain) even higher antibody titre than normal subjects. This has also a counterpart in the cell-mediated immune response as shown by the significant increase in the percentage of $\mathrm{B}$ lymphocytes, as compared to normal subjects, 1 week after vaccination at the time when the humoral immune response to the virus is maximal.

The marked immune response observed in patients with Type 1 diabetes, in particular to the $\mathrm{A} / \mathrm{Chile}$ strain, may be characteristic of these patients. Thus, at the time of diagnosis and even before the onset of clinical symptoms islet cell antibodies, activated T cells [19] and high increased antibody titre to Coxsackie B virus [20] are de- scribed in these patients. A genetic predisposition to an exaggerated immune response to exogenous stimuli can then be envisaged. Indirect support for this hypothesis comes from recent data showing that subjects possessing the HLA-DR3 phenotype (both susceptible and non-susceptible to diabetes) show a higher cell-mediated immune response compared to those with other HLA-DR allotypes [21]. Unfortunately, in our study the number of patients with Type 1 diabetes to whom the vaccine was given was too small to correlate the HLA phenotype with the virus antibody titre. The raised immunoreactivity observed in patients with Type 1 diabetes may be also linked to the general phenomenon of the highly specific antibody response for each virus subtype compared to cytotoxic T cells which, once generated, show cross reactivity in their recognition of the different subtypes of influenza virus [22]. The capacity of patients with Type 1 diabetes of generating a higher response to one particular virus subtype could reflect indeed the peculiar immune response of these patients.

A different pattern compared to Type 1 diabetic patients has been observed in patients with Type 2 diabetes. Overall, we did not find any difference between patients and age-matched control subjects in the humoral immune response to the different virus strains. However, the generation of activated cells, as defined by a monoclonal antibody which phenotypes cells possessing receptors for interleukin-2, was impaired $72 \mathrm{~h}$ following the antigenic challenge with the virus. Amongst patients with Type 2 diabetes there were 4 completely anergic $(19 \%)$; this percentage is higher than expected based on data in the normal population. Thus, several reports indicate that within healthy subjects only 1 out of 10 are non-responders to the vaccine $[2,3]$. It is unlikely that metabolic decompensation is implicated in the absence of an immune response in the 4 patients with Type 2 diabetes, as glycosylated haemoglobin levels were raised only in one patient. However, it should be pointed out that despite the lack of a specific immune response - as evaluated by our parameters - these 4 patients did not develop influenza later on.

In conclusion, antigenic challenge with the influenza virus has demonstrated that well controlled diabetic patients have a prompt humoral and cell-mediated immune response to the virus. If patients are well controlled and investigation of lymphocyte subsets does not reveal abnormalities, we would expect these patients to have effective immunization against influenza after vaccination. Indeed, none of our patients developed influenza in the course of the whole following year.

Acknowledgments. This work was supported by Grants from the Nordisk Foundation, the Anglo-Italian Fund for Research into Diabetic Vascular Disease and the Ministero P. I. Grant no. 02120102. The authors are indebted to $\mathrm{Mr} P$ Beales and to all physicians in the Outpatient Diabetic Clinic of II Clinica Medica of the University of Rome for collaboration in conducting the study and recruiting patients and volunteers. 


\section{References}

1. Tyrrell DAJ, Smith JWG (1979) Vaccination against influenza A. Br Med Bull 35: 77-85

2. Clark A, Potter CW, Jennings R, Nicholl JP, Langrick, Schild GC, Wood JM, Tyrrell DAJ (1983) A comparison of live and inactivated influenza A virus vaccines. 2. Long term immunity. J Hygiene 90: $361-370$

3. Powers, RD, Hayden FG, Samuelson J, Gwaltney JM (1984) Immune response of adults to sequential influenza vaccination. $J$ Med Virol 14: 169-175

4. National Advisory Committee on Immunization (1984) Influenza vaccination for the 1984-1985. Can Med Assoc J 131: 304-305

5. Barg M, Roth M, Ducey C, Arquilla ER (1980) Immunologic functions in diabetes. In: Irvine WJ (ed) Immunology of diabetes. Teviot Edinburgh, pp 299-307

6. Horita M, Suzuki H, Onodera T, Ginsberg-Fellner F, Fauci AS, Notkins AL (1982) Abnormalities of immunoregulatory T-cell subsets in patients with insulin dependent diabetes mellitus. J Immunol 129: 1426-1429

7. Mahmoud AAF, Rodman HM, Mandel MA, Warren KS (1976) Induced and spontaneous diabetes mellitus and suppression of cell mediated immunologic responses: granuloma formation, delayed dermal reactivity, allograft rejection. J Clin Invest 57 : 326-367

8. Bagdade JD, Nielson KL, Bulger RJ (1972) Reversible abnormalities in phagocytic function in poorly controlled diabetic patients. Am J Med Sci 263: 451-456

9. Iavicoli M, Di Mario U, Pozzilli P, Canalese J, Ventriglia L, Galfo C, Andreani D (1982) Impaired phagocytic function and increased immune complexes in diabetics with severe retinopathy. Diabetes 31:7-11

10. McCuish AC, Jordan J, Campbell CJ, Duncan LJP, Irvine WJ (1974) Phytohaemagglutinin lymphocyte transformation and circulating lymphocyte subpopulations in insulin dependent diabetes. Diabetes 23: 708-712

11. Pozzilli $P$, Zuccarini $O$, Iavicoli M, Andreani D, Sensi M, Spencer KM, Bottazzo GF, Beverley PCL, Kyner JL, Cudworth AG (1983) Monoclonal antibodies define abnormalities of $T$ lymphocyte subsets in diabetes. Diabetes 32: 91-94

12. Arquilla ER, Stenger D (1984) In: Immunology in diabetes, Andreani D, Di Mario U, Federlin KF, Heding LG (eds), Kingston Medical Edinburgh, pp 265-275
13. Oxford JS, Yetts R, Schild GC (1982) Quantitation and analysis of the specificity of post-immunization antibodies to influenza B viruses using single radial haemolysis. J Hyg $88: 325-333$

14. Haynes BF, Hemler ME, Mann DL, Eisenbarth GS, Shelhamer JH, Mostowski HS, Thomas CA, Strominger JL, Fauci AS (1980) Characterization of a monoclonal antibody (4F2) which binds to human monocytes and to a subset of activated lymphocytes. J Immunol 126:1409-1411

15. Leonard JJM, Depper T, Uchiyama T, Smith KA, Waldmann TA (1982) A monoclonal antibody that appears to recognize the receptor for human $T$ cell growth factor: partial characterization of the receptor. Nature 300:267-269

16. Hansen JA, Martin PJ, Nowinski RC (1980) Monoclonal antibodies identyfing a novel $\mathrm{T}$ cell antigen and Ia antigens of human lymphocytes. Immunogenetics 10: 247 260

17. Sensi M, Pozzilli P, Di Mario U (1984) A method to facilitate the reading of up to 60 samples of monoclonal antibody-fluorescence stained cells using Medicell HLA-DR plates. J Clin Lab Immunol 13: 101-102

18. Delespesse G, Duchateau J, Bastenie PA, Lavaux JP, Collett H, Govaerts A (1974) Cell mediated immunity in diabetes mellitus. Clin Exp Immunol 18: 461-466

19. Bottazzo GF, Pozzilli P, Mirakian R, Dean BM, Doniach D (1984) Early immunological events in diabetes. In: Immunology in diabetes. Andreani D, Di Mario U, Federlin KF, Heding LG (eds) Kimpton Medical, Edinburgh, pp 95-105

20. Banatvala JE, Bryant J, Schernthaner G, Borkenstein M, Schober E, Brown D, De Silva LM, Menser MA, Silink M (1985) Coxsackic $\mathrm{B}$, mumps, rubella and cytomegalovirus specific IgM responses in patients with juvenile onset insulin dependent diabetes mellitus in Britain, Austria and Australia. Lancet 1: 1409-1412

21. Pozzilli P, Tarn A, Gale EAM (1985) HLA-DR3 and activated lymphocytes: significance in autoimmunity. Lancet 2: 954-955 (Letter)

22. McMichael AJ, Gotch FM, Noble GR, Beare PAS (1983) Cytotoxic T-cell immunity to influenza. N Engl J Med 309: 13-17

Received: 11 March 1986

and in revised form: 13 October 1986

Dr. P. Pozzilli

Department of Diabetes and Immunogenetics

St. Bartholomew's Hospital,

London EClA 7BE, UK 